\title{
ASEXUAL PROPAGATION OF ARAÇÁ (Psidium cattleianum Sabine) BY LEAF AND YOUNG BRANCHES CUTTINGS ${ }^{1}$
}

Edwin Antonio Gutierrez Rodriguez ${ }^{2 *}$, Elisandra Maria Pradella ${ }^{3}$, Paulo Vitor Dutra de Souza ${ }^{4}$ and Gilmar Schafer ${ }^{5}$

\footnotetext{
${ }^{1}$ Received on 26.04.2013 accepted for publication on 22.06.2016.

${ }^{2}$ Universidade Estadual Paulista Júlio de Mesquita Filho, Faculdade de Ciências Agrárias e Veterinárias de Jaboticabal. Jaboticabal, SP - Brasil. E-mail: <edunillanos@hotmail.com>.

${ }^{3}$ Universidade Federal do Rio Grande do Sul, Graduada em Engenharia Agronômica, Porto Alegre - Brasil. E-mail: <elisandra.mp@hotmail.com>.

${ }^{4}$ Universidade Federal do Rio Grande do Sul, Faculdade de Agronomia, Departamento de Horticultura e Silvicultura. Porto Alegre, RS - Brasil. E-mail: <pvdsouza@ufrgs.br>.

${ }^{5}$ Universidade Federal do Rio Grande do Sul, Faculdade de Agronomia, Departamento de Horticultura e Silvicultura. Porto Alegre, RS - Brasil. E-mail: <schafer@ufrgs.br>.

*Corresponding author.
}

\begin{abstract}
Psidium cattleianum Sab., from Mirtaceae family, commonly known as araçá, is a native species form the South of Brazil, present in biomes such as the Atlantic Forest, a deciduous forest of Brazilian cerrado, strongly affected by the expansion of areas for agricultural and industrial production. Researches on plant breeding area, nutraceuticals and other areas have validated its potential and it detaches the need to promote it on a commercial scale. Mechanisms, that allow exploiting its genetic potential while maintaining its conservation areas, require adjustment in cloning techniques for fixing interest characteristics. In this investigation, seedlings of leaf cutting and young branch were assessed, with three treatments in leaf cutting $\left(\mathrm{H}_{2} \mathrm{PO}_{4} 0.2 \mathrm{gL}^{-1}\right.$, AIB $100 \mathrm{mg} \mathrm{L}^{-1}$ and AIB and powder-based applied over cutting region). Moreover, leaf cuttings of five cm length and the two leaves were treated with AIB $\left(0,1,500,3,000\right.$ and $\left.6,000 \mathrm{mg} \mathrm{L}^{-1}\right)$ in the absence and presence of BAP $\left(500 \mathrm{mg} \mathrm{L}^{-1}\right)$. Treatment with AIB (powder) in leaf cuttings showed higher survival of leave; however, there were callus formation, especially compared to other treatments of $\mathrm{H}_{2} \mathrm{PO}_{4}$ and AIB that showed average rooting percentage of $18 \%$. In plant cuttings, there were no significant difference for the variables evaluated between AIB doses; however, the use of cytokinin (BAP $500 \mathrm{mg} \mathrm{L}^{-1}$ ) was inhibitory. There was no difference at rooting percentage (98\%) without treatment with regulator, maintaining similar with BAP doses.
\end{abstract}

Keywords: Growth regulator; Native fruit; Plant propagation.

\section{PROPAGAÇÃO ASSEXUADA DE ARAÇAZEIRO (Psidium cattleianum Sabine) POR ESTACAS DE FOLHAS E RAMOS JOVENS}

\begin{abstract}
RESUMO - Psidium cattleianum Sab., família Myrtaceae, popularmente conhecida no Brasil como araçazeiro é uma espécie nativa do sul do Brasil, presente em biomas como a Mata Atlântica, Floresta Estacional Decídua e o Cerrado brasileiro, fortemente afetados pela expansão das áreas de cultivo e agroindústria. Pesquisas na área fitotécnica, nutracêutica e outras têm validado o seu potencial e destacado a necessidade de promovêla a escala comercial. Mecanismos que permitam explorar seu potencial genético, mantendo as áreas de preservação exigem o ajuste de técnicas de clonagem para a fixação de características de interesse. Nesta pesquisa, avaliou-se a produção de mudas por estacas de folhas e ramas jóvenes, com três tratamentos $\left(\mathrm{H}_{2} \mathrm{PO}_{4}\right.$ $0,2 \mathrm{gL}^{-1}, A I B 100 \mathrm{mg} \mathrm{L}^{-1}$ AIB em talco, aplicado por contato na região do corte). Além disso, estacas herbáceas de cinco centímetros de comprimento e duas folhas foram tratadas com AIB $\left(0,1500,3000\right.$ e $\left.6000 \mathrm{mg} \mathrm{L}^{-1}\right) \mathrm{na}$ ausência e na presença de BAP (500 $\left.\mathrm{mg} \mathrm{L}^{-1}\right)$. O tratamento com AIB (talco) nas estacas de folha mostrou maior sobrevivência, porém houve principalmente a formação de calos quando comparado com outros tratamentos de $\mathrm{AIB}$ e $\mathrm{H}_{2} \mathrm{PO}_{4}$ que mostraram porcentagem de enraizamento em média de $18 \%$. Nas estacas de ramo
\end{abstract}


jovem, não houve diferença significativa entre as variáveis avaliadas nas doses de AIB, por outro lado o uso de BAP (500 $\left.\mathrm{mg} \mathrm{L}^{-1}\right)$ foi inibitório. Não houve diferença no percentual de enraizamento (98\%) entre o tratamento sem regulador e as doses de BAP.

Palavras-chave: Frutifera nativa; Produção de mudas; Reguladores de crescimento.

\section{INTRODUCTION}

The conservation of biodiversity allows the great mass of chemical compounds, genetic resources and other benefits of terrestrial species are available to provide solutions to existing problems and those that are yet to be discovered (WILLIAMS et al., 2001). Psidium cattleianum Sabine is considered one of the native fruit species of Southern Brazil of great potential interest for its fruit, and ornamental, pharmaceutical and nutraceutical use, besides the environmental interest for its high production of fruits and seeds, considered another interesting feature from environmental point of view to the use in the recovery of native fauna and flora in deforested areas of the Atlantic Forest.

As $P$. cattleianum is still a native species of little research, there are no programs to reduce the genotypic variability within a population necessary for its commercial advantage. According to Rocha et al. (2008), there are two morphotypes that show anatomical differences: yellow and red.

In order preserve the homogenous agricultural characteristics, asexual propagation is an alternative. As a source of explants, it mainly uses cuttings, depending on plant area that may be apical, intermediate or radicular, ranging on explants characteristics. Propagation by cuttings has been researched and used in woody species such, as Pinus spp. (ANDREJOW; HIGA, 2009; ALCANTARA et al., 2007), Eucaliptus spp. (NAVARRETE and VARGAS, 2005), Psidium guajava (ZIETEMANN; ROBERTO, 2007) and ornamental (KÄMPF, 2005).

For technique success, preparation of cuttings is an important element. For example, in plant cuttings, the presence of young leaves may promote the synthesis of auxin, a source of carbohydrates and in turn, facilitated by the formation of less specialized cells (HOPPE et al., 2004), that is an important characteristic for relocation and reorganization of air and root system required for asexually formation of seedlings.

Revista Árvore, Viçosa-MG, v.40, n.4, p.707-714, 2016
However, morphogenesis depends on the interaction of physiological, chemical, histological factors, among others. In apical cutting, for example, for being the region of auxin synthesis, it facilitates the development of shoots; while in leaf cutting also reorient the translocation of photo-assimilated needed to induce the formation of shoot and root system.

In species of difficult response, the participation of propagation by cutting requires synthetic regulators, especially of the auxin group, which are more associated to the development of lateral roots (SMET et al., 2007). Meanwhile, the cytokinins group acts in various processes of growth and development of plants, including the promotion of cell division, delayed senescence and regulation of apical dominance, but it can also disturb the development of lateral roots by its increased concentration (DITENGOU et al., 2008) and trigger the programmed cell death in the zone of rhizogenesis response.

The application of regulators for rooting induction can be carried out on a commercial powder, concentrated alcoholic solutions or in low concentrations for leaf application. The immersion time of cuttings depends on the used concentration. Dilute solutions (0 to 500 $\mathrm{mg} \mathrm{L}^{-1}$ ) require hours into contact with tissue, while in low concentration $\left(>500 \mathrm{mg} \mathrm{L}^{-1}\right)$ require a few seconds (HARTTMAN et al., 2002).

In turn, the formation of plantlets by leaf cutting and bud represent also the cited above, histological restructuration and function changes. From an anatomical point of view, the cells of abaxial and adaxial surfaces differ in size and thickness, cell from apex and margin are generally thinner than the rest (CUTLER et al., 2011).

The physical aspects are also responsible for rooting induction. Suitable temperature affects the formation of roots, but its development is highly dependent on energy source (HARTMANN et al., 2002), this being the case of propagation by guava cuttings (Psidium guajava), wherein root formation depends on the maintenance of healthy leaves (ANDRADE, 2001).

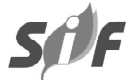


Cuttings from young branches rooting faster; however, require adequate installations and adequate control of the factors that affect its formation, being crucial to maintain leaf retaining. The control of these factors associated with the use of strategies, such as exogenous application of synthetic auxin and branch etiolation can increase the rhizogenesis capacity in guava cuttings (MARINHO et al., 2008).

The aim of this study was to evaluate the potential of two sources of cutting rooting using rooting inducers, as well as the effect of the cut type in cutting base.

\section{MATERIALAND METHODS}

The experiments were performed at the Biotechnology Laboratory of the Department of Horticulture and Forestry at Universidade Federal do Rio Grande do Sul, under greenhouse conditions without temperature control, with intermittent irrigation by misting, maintaining a relative humidity of $80 \%$ and an average temperature of $22.4^{\circ} \mathrm{C}$. Three experiments were performed, one of leaf cuttings and two using young branches. The stock plants were kept under greenhouse conditions with periodic fertilization on $5 \mathrm{~L}$ polypropylene bags and irrigated by dripping with three daily shifts of three minutes each.

For all three treatments, the experimental design was completely randomized, with four replications, and block was dependent on the location on greenhouse and experimental unit consists of ten explants arranged in honeycomb tray of plastic with cells from 20 $\mathrm{mL}$, totaling 40 explants per treatment. It was used charred rice husk as substrate, previously sterilized by moist heat on $1.3 \mathrm{~atm}$ pressure and at $120^{\circ} \mathrm{C}$ for 20 minutes.

When there was a significant difference in ANOVA, means were compared by Tukey test $(\mathrm{P}>0.05)$ using ASSISTAT (SILVA; AZEVEDO, 2002)

\subsection{Experiment 1. Propagation by leaf cuttings}

For propagation by leaf and node cutting, mature leaves were used of approximately $22 \mathrm{~cm}^{2}$ of laminar area obtained from plants in young stage, with no presence of flower branches at the time of establishment. The cutting was taken maintaining a leave with bud and about one centimeter and the region involves bud. Leaves were placed on the substrate were in a semi-inclined position to increase the perception of light.
The three treatments by contact with the cutting area with the product for rooting induction were: immersion for 18 hours in AIB solution $\left(0.1 \mathrm{~g} \mathrm{~L}^{-1}\right)$; immersion for 18 hours in $\mathrm{H}_{2} \mathrm{PO}_{4}$ solution $\left(0.2 \mathrm{~g} \mathrm{~L}^{-1}\right)$ and ascorbic acid $\left(5 \mathrm{~g} \mathrm{~L}^{-1}\right)$ for 10 seconds and commercial powder for rooting (AIB $10 \mathrm{~g} \mathrm{~kg}^{-1}$ ). The evaluated variables were: percentage of callus formation, rooting, survival and mass of roots or callus by cuttings.

\subsection{Experiment 2. Propagation by cuttings of young branches: growth regulators action}

For propagation by cuttings of young branches, mother-plants were pruned and arranged in semi-inclined position to increase the regrowth emission area. Cuttings of five $\mathrm{cm}$ length with two whole leaves were used as explants.

At the base of cuttings part of the phloem was removed and this region was submerged for ten seconds in solutions. Subsequently, cuttings were placed at an angle of $45^{\circ}$ in relation to $20 \mathrm{~mL}$ plastic tray. It used the same substrate and conditions of the Experiment 1.

Four AIB concentrations were evaluated (zero, 1,500, 3,000 and $6,000 \mathrm{mg} \mathrm{L}^{-1}$ ) in hydro alcoholic solution at $40 \%$ in the absence and presence of BAP $\left(500 \mathrm{mg} \mathrm{L}^{-1}\right)$, in accordance with subdivided plots, with BAP as the main plot and subplots the doses of AIB. It was evaluated the following variables: rooting percentage, volume, number and dry weight $(\mathrm{g})$ of roots per cutting:

\subsection{Experiment 3. Propagation by cuttings of young branches: cut types}

In parallel with the experiment 2 , the effect of three cut types on the base of the cutting (bevel cutting, double and straight bevel) in the formation of roots were evaluated. The following variables were assessed: number, mass $(\mathrm{g})$ and volume $(\mathrm{mL})$ of roots per cutting: The experiment was conducted under the same conditions as the previous, without the application of growth regulators.

\section{RESULTS}

\subsection{Experiment 1. Propagation by leaf cuttings and bud}

The three treatments with solution of $100 \mathrm{mg} \mathrm{L}^{-1} \mathrm{AIB}$ and $0.2 \mathrm{~g} \mathrm{~L}^{-1}$ of phosphoric acid $\left(\mathrm{H}_{2} \mathrm{PO}_{4}\right)$ showed low percentage of rooting $(18 \%)$, while the use of the regulator in powder (AIB $10 \mathrm{~g} \mathrm{~kg}^{-1}$ ) had a high percentage

Revista Árvore, Viçosa-MG, v.40, n.4, p.707-714, 2016

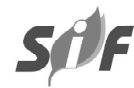


of live cuttings with callus formation at the base and rooting percentage almost null (3\%) (Table 1).

By the time of the evaluation of the experiment, cuttings of any treatments showed development of air structure (Figure 1b).

\subsection{Experiment 2. Propagation by cuttings of young branches: growth regulators action}

In the absence of BAP, AIB treatments showed more than $97 \%$ of rooting. The use of BAP $\left(500 \mathrm{mg} \mathrm{L}^{-1}\right)$ showed inhibitory effect for all variables with no statistical difference between treatments (Table 2). However, at the same concentration of BAP, in any of the assessed variables were significant differences between the doses of AIB (Table 2).

\subsection{Experiment 3. Propagation by cuttings of young branches: cut types}

Based on the cutting effect on the rooting, the cut types test on basis cutting without treatment with regulator showed that the number of roots per cut was significantly higher in straight cut compared to those that were beveled cut. The average volume of roots per cutting was $0.89 \mathrm{~mL}$, with no significant difference between treatments (Table 3 ).

\section{DISCUSSION}

\subsection{Experiment 1. Propagation by cuttings of leaves}

Peixe et al. (2007) in the propagation by cuttings of Olea europaea L., observed that ontogeny of mass cell named callus, it would be closely linked by its subsequent differentiation from parenchyma cells, the subsequent formation of adventitious roots. In turn, Quadros (2009), in the propagation of plant cuttings of Ilex paraguariensis observed a positive correlation between the percentage of callus formation and survival;

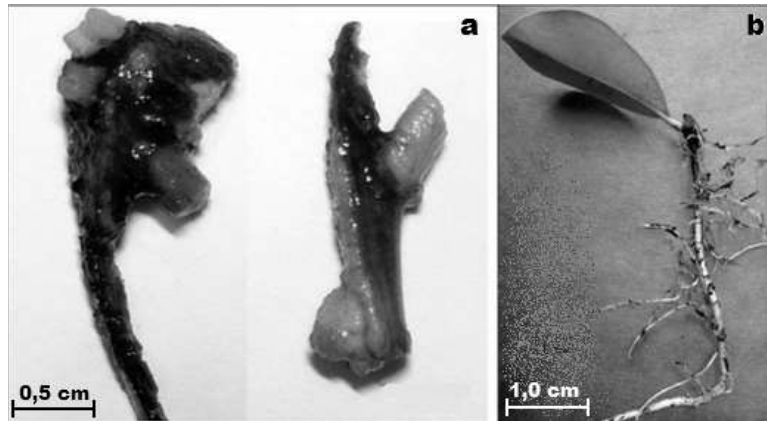

Figure 1 - Cut detail of $P$. cattleianum leaf cuttings. thirty days after the establishment for root induction: a. callus formation. b. root formation, UFRGS, Porto Alegre, 2016.

Figura 1-Detalhe do corte em estacas de folha de araçazeiro trinta dias após estabelecimento em condições de sala de nebulização: a. formação de calo, b, formação de raiz, UFRGS, Porto Alegre, 2016.

Huetteman and Preece (1993), on the other hand, recognize that callus formation is a preliminary step in the regeneration of adventitious organs, but this may become inhibitory on woody species.

The propagation technique by leaf cutting has been successfully used in the propagation of other horticultural crops such as cassava and potato (CIAT, 1983) and with a moderate level of rooting on species such as avocado (Persea americana), but without the development of shoot, which was achieved only plant production using semi-woody cuttings (FERREIRA, 2008), similar to the results obtained in Cedrela fissilis (XAVIER et al., 2003).

The priorization in the formation of root structures, reported with $P$. americana (FERREIRA, 2008) and Cedrela fissilis (XAVIER et al., 2003), is possibly caused by physiological structures prioritizing for the absorption of nutrients.

Table 1 - Effect of treatment on leaf cutting rooting after 120 days. Callus formation (C), rooting (R), death (M) root dry matter per cutting (R) and callus (C), UFRGS, Porto Alegre, 2016.

Tabela 1 - Efeito do tratamento no enraizamento de estacas de folha após 120 dias de estabelecimento. Formação de calo $(C)$, enraizamento (R), morte (M) e massa seca de raiz por estaca (R) e calo (C), UFRGS, Porto Alegre, 2016.

\begin{tabular}{|c|c|c|c|c|c|}
\hline \multirow[t]{2}{*}{ Treatment } & \multicolumn{3}{|c|}{ Percentage } & \multicolumn{2}{|c|}{ Dry matter (gr) } \\
\hline & Callus & Root & Died & Callus & Root \\
\hline 1 -IBA in solution $\left(100 \mathrm{mg} \mathrm{L}^{-1}\right)$ & $45^{b}$ & $18^{\mathrm{a}}$ & $35^{\mathrm{b}}$ & $0.25^{\mathrm{ns}}$ & $0.095^{\mathrm{ns}}$ \\
\hline $2-\mathrm{H}_{2} \mathrm{PO}_{4}$ in solution $\left(0.2 \mathrm{~g} \mathrm{~L}^{-1}\right)$ and Ascorbic acid $5 \mathrm{~g} \mathrm{~L}^{-1}$ & $18^{\mathrm{c}}$ & $18^{\mathrm{a}}$ & $65^{\mathrm{a}}$ & 0.23 & 0.95 \\
\hline 3 -IBA in industrial powder $\left(10 \mathrm{~g} \mathrm{~kg}^{-1}\right)$ & $75^{\mathrm{a}}$ & $3^{\mathrm{b}}$ & $23^{\mathrm{b}}$ & 0.23 & 0.08 \\
\hline Mean (\%) & 46 & 13 & 41 & 0.24 & 0.09 \\
\hline C.V \% & 18.9 & 46 & 22.7 & 22.14 & 31.3 \\
\hline
\end{tabular}

Revista Árvore, Viçosa-MG, v.40, n.4, p.707-714, 2016 
Table 2 - Rooting percentage (\%) Root volume per cutting $(\mathrm{mL})$, number of roots per cutting, root dry mass (MSR) in the propagation of $P$. cattleianum by cutting using different doses de of BAP and AIB. UFRGS, Porto Alegre, 2016.

Tabela 2 - Percentual de enraizamento (\%), volume de raiz por estaca $(\mathrm{mL})$, número de raízes por estaca, massa seca de raiz (MSR) na propagação de P.cattleianum por estaca herbácea, utilizando diferentes doses de BAP e AIB. UFRGS, Porto Alegre, 2016.

\begin{tabular}{|c|c|c|c|c|c|}
\hline $\begin{array}{c}\text { BAP } \\
\text { Concentration } \\
\left(\mathrm{mg} \mathrm{L}^{-1}\right)\end{array}$ & $\begin{array}{c}\text { IBA } \\
\text { Concentration } \\
\left(\mathrm{mg} \mathrm{L}^{-1}\right)\end{array}$ & Rooting (\%) & $\begin{array}{l}\text { Root volume } \\
\text { by cutting } \\
(\mathrm{mL})\end{array}$ & $\begin{array}{c}\text { number of roots } \\
\text { by cutting }\end{array}$ & $\begin{array}{c}\text { root dry matter } \\
\text { and mean }\end{array}$ \\
\hline \multirow[t]{4}{*}{0} & 0 & $98 \mathrm{~ns}$ & $2.23 \mathrm{~ns}$ & $7.4 \mathrm{~ns}$ & $21.59 \mathrm{~ns}$ \\
\hline & 1500 & 100 & 3.13 & 9.45 & 21.89 \\
\hline & 3000 & 95 & 2.63 & 10.88 & 26.96 \\
\hline & 6000 & 98 & 3.25 & 9.53 & 22.24 \\
\hline Mean & & $97.75 \mathrm{a}$ & $2.81 \mathrm{a}$ & $9.315 \mathrm{a}$ & $23.17 \mathrm{a}$ \\
\hline \multirow[t]{4}{*}{500} & 0 & 83 & 1.50 & 5.73 & 8.63 \\
\hline & 1500 & 85 & 1.25 & 5.05 & 9.67 \\
\hline & 3000 & 68 & 0.95 & 3.81 & 6.76 \\
\hline & 6000 & 75 & 0.98 & 4.99 & 7.73 \\
\hline Mean & & $77.75 \mathrm{~b}$ & $1.17 \mathrm{~b}$ & $4.895 \mathrm{~b}$ & $8.1975 \mathrm{~b}$ \\
\hline Data transf. & & $\operatorname{arcsen} x$ & $\operatorname{raiz}(x+1)$ & & \\
\hline $\mathrm{P}$ value (BAP) & & $<0.001$ & $<0.001$ & $<0.001$ & $<0.001 \mathrm{P}$ \\
\hline value (IBA) & & 0.284 & 0.615 & 0.922 & $0.942 \mathrm{P}$ \\
\hline value (BAP x AIB) & & 0.908 & 0.179 & 0.314 & 0.557 \\
\hline $\mathrm{CV} \%$ & & 27.2 & 35.1 & 16.96 & 35.5 \\
\hline
\end{tabular}

Table 3 - Effect of cut type on cuttings of young branches of P. cattleianum, a. number of roots, b. dry weight, c. volume of roots per cutting. UFRGS. Porto Alegre. 2016.

Tabela 3 - Efeito do tipo de corte no enraizamento de estacas de ramas jovens de $\boldsymbol{P}$. cattleianum, a. número de raízes, b. massa seca, c. volume de raizes por estaca enraizada. UFRGS, Porto Alegre, 2016.

\begin{tabular}{lccc}
\hline Cut Type & Number of roots & Dry weight & Volume \\
\hline Horizontal & $7.41 \mathrm{a}$ & $30.16 \mathrm{a}$ & $0.75 \mathrm{~ns}$ \\
Simple bisel & $5.13 \mathrm{~b}$ & $20.39 \mathrm{~b}$ & 1.02 \\
Double bisel & $5.67 \mathrm{ab}$ & $26.47 \mathrm{ab}$ & 0.92 \\
Average & 6.07 & 25.67 & 0.89 \\
CV \% & 49.00 & 0.30 & 9.90 \\
P value & 0.012 & 0.004 & 0.34 \\
\hline
\end{tabular}

Not differ at the level of $5 \%$ probability of error by Tuckey test. $* * \mathrm{Ns}=$ not significant.

\subsection{Experiment 2. Propagation by cuttings of young branches: growth regulators action}

Hartmann et al. (2002) indicate that callus formation on cuttings is indicative of suitable environmental conditions for rooting. However, no formation in young seedlings but in adults is indicative of low joviality. Under this premise, the incubation conditions of this experiment were favorable to morphogenesis.

Among treatments, the 6- benzylaminopurine (6-BAP) of cytokinins group associated to the stimulation of cytokinesis and subsequent development of axillary meristems, key in the propagation by cuttings evaluated in this experiment, has showed inhibitory. According to Skoog and Miller (1957), the hormonal group of cytokinin, which BAP is part, is related with cytokinesis stimuli, generating responses in growth of axillary meristems (MOTYKA et al., 1996).

The response to auxin in tissues, of asymmetrical presence in stem and root is defined, among other factors, by its location. Based on the above, the presence of cells less specialized in juvenile tissue, site of auxin synthesis and lower degree of cell differentiation, promote the formation of adventitious roots (DAVIES, 2010).

A greater rhizogenesis response of tissues without the use of auxinic compounds of synthesis can be also correlated with low degree of lignification of cuttings, being this last can become limiting. In the propagation of $P$. cattleianum, young shoots of adult plants showed

Revista Árvore, Viçosa-MG, v.40, n.4, p.707-714, 2016 
greater ability of rooting compared to more lignified explants (FACHINELLO et al., 2005). Olesen (1978) suggest that the use of this kind of explants obtained from stock plants in juvenile stage can reduce the effect associated with topophysis.

Considering the high percentage of cuttings observed with callus formation, both, propagation by leaf cuttings and young branches, freehand cuts were performed in rooting region of cuttings in various stages of formation. The cuts suggest that the mass of callus is not a rooting pioneer (Figure $2 \mathrm{~d}$ and Figure $2 \mathrm{~b}$ ), and this shown as a cellular mass that covers the cut region (Figure 2c) and that its formation can be avoided with early appearance of roots (KOMISSAROV, 1968), while the last ones differed from pro-exchange (2f) of the tissue where there was no cut (Figure 2a) and (Figure 2-e). Other authors reported that the formation of of adventitious roots primordia begins by parenchyma cell division similar the divisions that originate lateral roots in pericycle primary roots (CALDERON et al., 2004), or this is favored when xylem and phloem tissues are exposed by cuts (FACHINELLO et al., 1995)

\subsection{Experiment 3. Propagation by cuttings of young branches: cut types}

According to Baltierra et al. (2004), the formation of root adventitious occurs from cell divisions in the cortical parenchyma region, similar to those that originate secondary roots in pericycle. In $P$. cattleianum, roots formed in this section not affected by cut, whereas in the present, there was no formation of scar callus (Figure 2e), which shows that the practice of double cut does not increase the formation of roots of this species.

\section{CONCLUSIONS}

Under the experimental conditions, it is concluded that:

- P. cattleianum is easy rooting through the propagation by cuttings.

- There was root induction in plant cuttings without AIB use.

- The straight cut in the cuttings is most suitable for root formation.

- Propagation by leaf cutting shows low potential for root formation.

Revista Árvore, Viçosa-MG, v.40, n.4, p.707-714, 2016
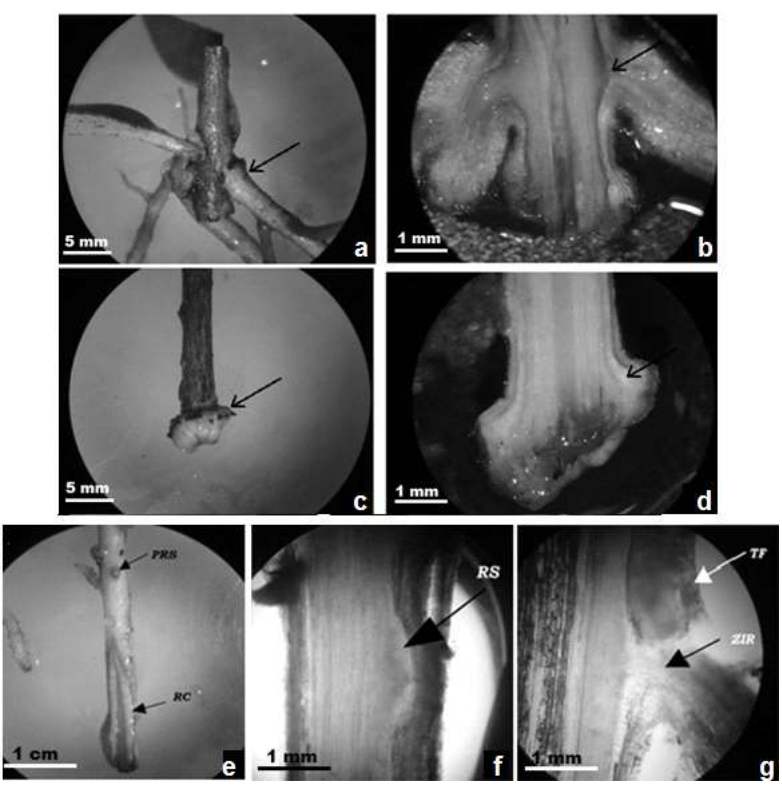

Figure 2 - Freehand cut of rooting zone in cuttings of $P$. cattleianum. a. primary root. b. Detail of the formation of lateral roots. c. callus formation on cutting base. $d$. Freehand cut showing callus region, e: The formation of root primordia (PRS) and callus outside the cutting area (RC), f: longitudinal stem section showing the beginning of the formation of secondary root (RS), $g$ : Development of secondary roots in vascular exchange region (ZIR) through the phloem (TF). UFRGS, Porto Alegre, 2016.

Figura 2 - Corte a mão livre da zona de enraizamento em estacas herbáceas de P. cattleianum, a. raiz primaria, b. Detalhe da formação de raízes laterais, $c$. Formação de calo na base da estaca, d. Corte a mão livre da região de formação do calo na base de estaca, e: Formação dos primórdios radiculares (PRS) e calo fora da região do corte $(R C), f$ : Corte longitudinal do caule mostrando o inicio de formação da raiz secundaria (RS). $g$ : Desenvolvimento de raiz secundaria na região do câmbio (ZIR) (TF). UFRGS, Porto Alegre, 2016.

\section{ACKNOWLEDGMENTS}

To COLCIENCIAS, CNPq, FAPERGS and CAPES by financial support and the Department of Horticulture and Forestry of UFRGS, especially Mr. Idenir José de Conto.

\section{REFERENCES}

ALCANTARA, G.B.; RIBAS, L.L.F.; HIGA, A.R.; RIBAS, K.C.Z.; KOEHLER, H.S. Efeito da idade da muda e da estação do ano no enraizamento de 
miniestacas de Pinus taeda L. Revista Árvore, v.31, n.3, p.399-404, 2007.

ANDREJOW, G.M.P.; HIGA, A.R. Potencial de enraizamento de miniestacas de Pinus taeda L. provenientes de brotação apical de mudas jovens. Floresta, v.39, n.4, p.897-903, 2009.

ANDRADE, A.L. Enraizamento adventício de estacas herbáceas de goiabeira (Psidium guajava L.) em função da variedade, condições de luz das plantas matrizes e tratamento das estacas com ácido indolbutírico. 2001. 85f. Dissertação (Mestrado em Fitotecnia) - Universidade Federal de Viçosa, Viçosa, MG, 2001.

BALTIERRA, X.C.; MONTENEGRO, G.; DE GARCIA, E. Ontogeny of in vitro rooting processes in Eucalyptus globulus. In vitro Cellular \& Developmental Biology Plant, v.40, n.5, p.499-503, 2004.

CALDERON, B.; MONTENEGRO, G.; GARCÍA, E. Ontogeny of in vitro rooting processes in Eucalyptus globulus. In Vitro Cellular and Developmental Biology - Plant, v.40, n.5, p.499-503, 2004.

CIAT. Global Workshop on Root and Tuber Crops Propagation Proceedings of a Regional Workshop held in Cali, Colombia, 13-16 Sept., 1983.

CUTLER, D.F.; BOTHA, T.; STEVENSON, D.Wm. Anatomia vegetal: uma abordagem aplicada. Porto Alegre: Artmed, 2011.304p.

DAVIES, P.J. Regulatory factors in hormone action: Level, location and signal transduction. In: DAVIES, P.J. Plant Hormones. New York: Cornell University, 2010. p.16-35.

DITENGOU, F.A.; TEALE, W.D.; KOCHERSPERGER, P.; FLITTNER, K.A.; KNEUPER, I.; GRAAFF, E.V.D.; NZIENGUI, H.; PINOSA, F.; LI, X.; NITSCHKE, R.; LAUX, T.; PALME, K. Mechanical induction of lateral root initiation in Arabidopsis thaliana. Procedures National Academic Science USA, v.105, p. 18818-18823, 2008.

FACHINELLO, J.C.; HOFFMANN, A.; NACHTIGAL, J.C.; KERSTEN, E.; HOFFMANN,
A.; NACHTIGAL, J.C.; KERSTEN, E. Propagación vegetativa por estaquia. In: FACHINELLO, J.C.; HOFFMANN, A.; NACHTIGAL, J.C.; KERSTEN, E.; HOFFMANN, A.; NACHTIGAL, J.C.; KERSTEN, E. Propagación de plantas frutíferas. Brasília: Embrapa Informacão Tecnológica, 2005. p.69-108.

FERREIRA, B.D. Propagação de abacateiro (Persea sp.) por estaquia e mergulhia. 2008. 85 f. Dissertação (Mestrado em Fitotecnia) - Programa de Pós-Graduação em Fitotecnía, Universidade Federal do Rio Grande do Sul, Porto Alegre, 2008

HARTMANN, H.T.; KESTER, D.E. Plant propagation: principles and practices. 7 th ed. New York: Englewood Clipps/Prentice Hall, 2002. 880 p.

HOPPE, J.S.; GENRO, C.J.M.; VARGAS, C.O.; FLORIANO, E.P.; REIS, E.R.; FORTES, F.O.; MÜLLER, I.; FARIAS, J.A.; CALEGARI, L.; DACOSTA, L.P.E. Produção de sementes e mudas florestais. 2.ed. Santa Maria: UFSM/ PPGEP, 2004. 388p. (Caderno didático, 1).

HUETTEMAN, C.A.; PREECE, J.E. Thidiazuron: a potent cytokinin for woody plant tissue culture. Plant Cell, Tissue and Organ Culture, v.33,p.105-119, 1993.

KÄMPF, A.N. Produção comercial de plantas ornamentais. Guaiba: Agrolivros, 2005. 256p

KOMISSAROV, D.A. Biological basics for the propagation of wood plants by cuttings. Jerusalem: IPST Press, 1968. 250p.

MARINHO, C.S.; MILHEM, M.A.; ALTOÉ, J.A.; BARROSO, D.G.; POMMER, C.V. Propagação da goiabeira por miniestaquia. Revista Brasileira de Fruticultura, v.31-32, p.607611,2008

MOTYKA, V.; FAISS, M.; STRNAD, M.; KAMÍNEK, M.; SCHMÜLLING, T. Changes in cytokinin content and cytokinin oxidase activity in response to derepression of $i$ 't cene transcription in transgenic tobacco calli and plants. Plant Physiology, v.112, p.10351043,1996

Revista Árvore, Viçosa-MG, v.40, n.4, p.707-714, 2016 
NAVARRETE-LUNA, M.; VARGAS-HERNÁNDEZ, J. Propagación asexual de clones de Eucalyptus camaldulensis utilizando radix en diferentes concentraciones. Revista Chapingo, v. 11, n.2, p.111-166, 2005.

OLESEN, P.O. On cyclophysis and topophysis. Silvae Genetica, v.27, p.173-178, 1978.

PEIXE, A.; SERRAS, M.; CAMPOS, C.; ZAVATTIERI, M.A.; DIAS, M.A.S. Adventitious rooting in olive (Olea europaea L.) cuttings: A histological evaluation. Revista de Ciências Agrárias, v.30-1, p.476-482, 2007.

QUADROS, K.M. Propagação vegetativa de erva mate (Ilex paraguariensis Saint HilaireAquifoliaceae). 2009. 69f. Dissertação (Mestrado em Engenharia Florestal) - Universidade Federal de Santa Maria, Santa Maria, 2009.

ROCHA, L.D.; PREUSSLER, K.H.; PEGORINI, F.; FARIAS, V.; MARANHO, L.T. Estudo anatômico comparativo da casca do caule do araçá-amarelo e araçá-vermelho, Psidium cattleianum Sabine, Myrtaceae. Revista Acta Botanica

Brasilica, v.22-4, p.1114-1122, 2008

SILVA, F.A.S.; AZEVEDO, C.A.V. Versão do programa computacional Assistat para o sistema operacional Windows. Revista Brasileira de Produtos Agroindustriais, v.4, p.71-78, 2002.

SKOOG, F.; MILLER, C.O. Chemical regulation of growth and organ formation in plant tissue cultures in vitro. Symposia of the Society for Experimental Biology, v.11, p.118-131, 1957.

SMET, I.; TETSUMURA, T.. Auxin-dependent regulation of lateral root positioning in the basal meristem of Arabidopsis. Development, v.134, p.681-690, 2007.

WILLIAMS, J.; READ, C.; NOTON, T.; DOVERS, S.; BURGMAN, M.; PROCTOR, W.; ANDERSON, H. Biodiversity. Canberra: Australia State of the Environment Report, 2001.

XAVIER, A.; SANTOS, G.A.; OLIVEIRA, M.L. Enraizamento de miniestaca caulinar e foliar na propagação vegetativa de cedro-rosa (Cedrela fissilis vell.). Revista Árvore, v.27, n.3, p.351356,2003 .

ZIETEMANN, C.; ROBERTO, S.R. Produção de mudas de goiabeira (Psidium guajava L.) em diferentes substratos. Revista Brasileira de Fruticultura, v.29-1, p.137-142, 2007. 